\title{
CIVIL LIABILITY OF GOVERNMENT OFFICERS: PROPERTY RIGHTS AND OFFICIAL ACCOUNTABILITY*†
}

\author{
JeRRY L. MASHaW** \\ INTRODUCTION
}

The law under which government officials operate permits them to inflict injury on others, under prescribed circumstances, in established ways, and in carefully (and sometimes not so carefully) calibrated amounts. Indeed, the law goes further: it sometimes tells the official that a failure to injure-that is, to coerce compliance with a predetermined rule of conduct-is a dereliction of official duty. For although there may be interminable argument over the social goals that justify the state in using force, all but the most extreme libertarians concede some place to governmental, and therefore official, coercion.

The legal system's permitting—or requiring—officially inflicted harms need not, however, be viewed as meaning that official harms have a peculiar legal position. At its most general level the law governing civil liability imposes an obligation to repair any negligent or intentional harm inflicted upon another. ${ }^{1}$ This liability rule obtains unless the harmful action can be justified by appeal to special circumstances. ${ }^{2}$ When harmful action is authorized by the statutes, regulations, customs, and interpretations empowering and instructing officials, such authorization may be viewed as merely one form of justification. Neither the constable who enters blackacre pursuant to a valid warrant nor the buyer who enters pursuant to a contract of sale will be held liable for trespass.

But in fact, the major legal rules that govern the civil liability of government officers seem to be quite different from the model sketched above that harm requires reparation unless authorized. Indeed, the basic proposition governing official liability might be stated: Harm requires reparation unless

\footnotetext{
* This paper was originally presented, in a slightly different form, at the Liberty Fund, Inc., Seminar on Civil Liability and Government Officials, administered by the Law and Economics Center of the University of Miami School of Law (April 15-17, 1977). No attempt has been made to take account of developments occurring after the date of the seminar.-Ed.

$\dagger$ The author wishes to acknowledge with gratitude the able assistance of Mark Goldberg of the Yale Law School, who did yeoman service in documenting this article.

** Professor of Law, Yale Law School.

1. See, e.g., LA. Civ. Code, Ann. art. 2315 (West 1870 as amended 1960).

2. Although this is the general mode of analysis employed by Epstein, $A$ Theory of Strict Liability, 2 J. Legal STUd. 151 (1973) and Defenses and Subsequent Pleas in a System of Strict Liability, 3 J. LEGAL STUD. 165 (1974), we shall here consider actions sounding in negligence rather than strict liability.
} 
inflicted by an official. It is customarily considered legally irrelevant whether the circumstances authorizing infliction of official harms were absent, whether the harm was excessive, or whether the manner of deciding upon and inflicting injury was irregular. The general rule is that an officer is immune.

The purpose of this paper is to examine the rationale for the officialimmunity doctrine. Because the purpose of this symposium is to articulate criteria for imposing civil liability on officers rather than to explore the many contours of the existing immunity doctrine, my task is to discuss the conditions under which individual civil liability should be imposed for officially inflicted harms. In approaching this subject I will make the not too heroic assumption that the purpose of imposing civil liability on officers has much more to do with providing incentives for appropriate conduct (i.e., deterrence) than with repairing damage previously caused (i.e., compensation). This assumption is not premised on a belief that deterrence theories of civil liability fully explain existing liability rules; ${ }^{3}$ it responds rather to the realization that the government itself is a potential defendant when its officers err and that the Treasury provides a virtually inexhaustible, and on that account superior, compensation fund. ${ }^{4}$ Moreover, terms such as "incentives" or "deterrence" are particularly appropriate to this subject, for no jurisprudence focuses more explicity on the incentive effects of civil liability than the jurisprudence of official immunity.

The paper will also be limited to civil actions based on negligence (that is, failure to exercise due care under the circumstances), the standard usually considered appropriate in suits for damages against officers. ${ }^{5}$ But even with this limitation, and with the limitation to incentive effects, the subject remains highly complex. I shall therefore outline briefly how the discussion will proceed.

Section I of this article explores the range of harms caused by government officers as they carry out their various duties. As this discussion demonstrates, officers sometimes inflict special types of harm, that is, harms without close similarity to private civil wrongs. We must therefore consider whether officials should have special duties, either of care or of affirmative action. This issue is explicity addressed in section IV, where it is referred to as the cause-of-action problem.

3. Compare Epstein, supra note 2, with Posner, Strict Liability: A Comment, 2 J. Legal. STUd. 205 (1973) and Fletcher, Fairness and Utility in Tort Theory, 85 HARv. L. REv, 537 (1972).

4. A compensation theorist would clearly find sovereign immunity a more fruitful topic of inquiry, and although some mention of governmental liability will be inevitable, this paper speaks primarily to of ficers' liability.

5. Negligence is the most stringent standard of care considered in this paper. It is meant to include liability based on recklessness or willfulness. Strict (i.e., no-fault) liability may well be an appropriate standard for determining governmental responsibility for harms resulting from certain hazardous activities, but it hardly seems appropriate as a standard for official accountability in damages 
Next, section II portrays the existing law of official immunity. That tale is indeed long and ultimately ambiguous: the plot reflects a judicial preference for Joyce and Beckett over Lardner and Twain. A sketch of the jurisprudence, highlighting the policy concerns that the courts have explicitly expressed, will therefore have to suffice. Moreover, the description will be limited to federal law: variations among state official-immunity doctrines in legal language and in legal and political history are of interest only to the connoisseur.

Section III analyzes the alternatives to civil liability as a control on official behavior. Individual civil liability for officers would operate in a context of existing incentives and disincentives, including (1) current procedures for selection, tenure, compensation, and advancement; (2) executive-branch supervision; (3) procedural requirements for official action; (4) political oversight; and (5) judicial review. Can these existing legal and institutional constraints provide appropriately structured incentives and effectively communicate information about them to officials?

Section IV discusses the effects of individual civil liability on the behavior of government officials in terms of a property-rights model of official behavior. This model implicitly contains the presuppositions made in microeconomics that decisionmaking will be rational; yet the judgments thereby derived about the imposition of civil liability on government officials are also supportable through modes of analysis that either presume a "satisficing" approach to decisionmaking or regard some more complex political process as accounting for bureaucratic behavior. ${ }^{6}$

The range of this inquiry is obviously very broad: it encompasses, potentially, all of the principles of civil liability and administrative law. Moreover, it attempts to consider the effects of these principles, and modifications of them, on official behavior. We thus enter simultaneously the domains of microeconomics and micropolitical theory as applied to public institutions and public officials. Even where assertive, therefore, the paper should be read as questioning. Virtually every statement is in some way problematic. The goal is to provide structure within which discussion can go forward.

I

The Many Faces of Officially Inflicted Harm

\section{A. Enforcement}

Harmful actions by government officials engaged in enforcement are commonplace, as are lawsuits complaining of them, though success in these

6. For a general description of these models in another context and a somewhat different conclusion concerning their implications, see Note, Decision-making Models and the Control of Corporate Crime, 85 YALE L.J. 1091 (1976). 
suits is less common. Federal officers enter, search, seize, and sometimes confiscate with obvious offense to person and property. Indeed, warrantless and unreasonable invasion of private premises has given rise to a federal cause of action against federal law-enforcement officers that is based on the Constitution. ${ }^{7}$ But while physical invasions constitute a substantial portion of harmful and allegedly unwarranted official enforcement activity, enforcement actions may injure without touching. Harmful publicity may constitute the nextlargest class of litigated actions. Press releases announcing that products are dangerous, that claims are false, or that governmental enforcement action is contemplated can have a devastating effect. ${ }^{8}$ When such announcements turn out to be baseless, the citizen or firm rightfully feels aggrieved.

Moreover, enforcement may be proper but inept. In a recent case calling for enforcement by the National Labor Relations Board of a back-pay order, a company complained, not because back pay was unwarranted, but because specification of the amount and the parties to whom it was owed was so slow that the company paid an estimated $\$ 180,000$ in awards that might have been prevented by reasonably prompt notice of liability. ${ }^{\mathbf{9}}$

Similarly, countless individuals or firms may be injured by official failure to take action. Pesticides remain in use after massive scientific evidence of their harmfulness has been collected. ${ }^{10}$ Ineffective drugs linger on the market. ${ }^{11}$ Competitors are allowed to continue violations of the Robinson-Patman Act or other statutes after the Federal Trade Commission has taken enforcement action against only a few firms. ${ }^{12}$ The facts in Smith $v$. U.S. provide a striking example of injustice resulting from such underenforcement. ${ }^{13} \mathrm{Mr}$. Smith, a grocery store owner, was called for jury service in a federal civilrights case and subsequently participated in a verdict for the plaintiff. Within a few months he was driven out of business because his customers were harassed and his business boycotted by persons seeking retaliation for the verdict. Although the federal-criminal-code violation was evident, ${ }^{14}$ the federal prosecutor stood by while Smith's business was destroyed.

7. Bivens v. Six Unknown Named Agents of the Federal Bureau of Narcotics, 403 U.S. 388 (1971).

8. See generally Gellhorn, Adverse Publicity by Administrative Agencies, 86 Harv. L. Rev. 1380 (1973).

9. J.H. Rutter Rex Mfg. Co. v. United States, 515 F.2d 97 (5th Cir. 1975). (We might note that the court of appeals held that the discretionary-function exception in the Federal Tort Claims Act precluded recovery. See note 67 infra and accompanying text.)

10. See, e.g., Environmental Defense Fund, Inc. v. Ruckelshaus, 439 F.2d 584 (D.C. Cir. 1971); Environmental Defense Fund, Inc. v. Hardin, 428 F.2d 1093 (D.C. Cir. 1970).

11. See, e.g., American Public Health Ass'n v. Veneman, 349 F. Supp. 1311 (D.D.C. 1972).

12. See, e.g., FTC v. Universal Rundle Corp., 387 U.S. 244 (1967); Moog Industries, Inc. v. FTC, 355 U.S. 411 (1958).

13. 375 F.2d 243 (5th Cir. 1967).

14. It is a federal crime to injure "any .. grand or petit juror in his person or property on account of any verdict or indictment assented to by him." 18 U.S.C. $\$ 1503$ (1970). 


\section{B. Authorizations}

Government officers not only enforce prohibitions but also authorize, grant, or-alternatively-deny needed official permission. Licensing functions are too well known, too ubiquitous, to require extended discussion here. But we should perhaps remind ourselves that an extraordinarily broad range of activities require governmental permission: ${ }^{15}$ driving an automobile, practicing law, contracting with the government, building a dock, discharging waste into navigable waters, adding a room to a house, offering a truck for hire in interstate commerce, or charging certain rates or rents. The injuries that flow from wrongful denials of permission are equally varied, ranging from simple loss of profits or profitable opportunity to loss of a lifetime investment in professional development to serious, and perhaps permanent, social stigma.

Nor is the harm that can result from government authorization or licensing limited to that consequent on improper denial. Food and Drug Administration certification of a too-virulent strain of vaccine ${ }^{\mathbf{1 6}}$ or Federal Aviation Administration certification of dangerous airline equipment can have obviously disastrous consequences. And widespread economic harm may result when licensing has the effect of granting a monopoly but not of exerting the price or quality controls that the statutory licensing scheme also intended. ${ }^{17}$ We are at least as concerned that licensing authorities should provide the protection they purport to provide as we are that they permit activity that is socially useful.

It is perhaps worthwhile to point out that government officers may manage, through a single exercise of their licensing powers (or other functions), to injure both the parties meant to be protected by the licensing scheme and those meant to be regulated. Golden Holiday Tours $v . C A B^{18}$ is a recent example. The plaintiff organized foreign charter flights that were subject to Civil Aeronautics Board approval of its arrangements. Because reservations were sold through many travel agents, the plaintiff estimated its number of passengers when contracting with air carriers, filed those contracts with the Board well ahead of the departure dates, and planned to make amendments to its filings should additional capacity be required. In this instance the $C A B$ rejected the plaintiff's request for an amendment to its westbound charters from Europe on the ground that the request was not timely under $\mathrm{CAB}$ regulations.

Although technically late, the amendment was filed as soon as the plaintiff, acting in accord with the customary practice of the industry, had responded

15. See, e.g., Gellhorn, The Abuse of Occupational Licensing, 44 U. CHI. L. Rev. 6 (1976).

16. See Griffin v. United States, 500 F.2d 1059 (3d Cir. 1974).

17. Cf. Rockbridge v. Lincoln, 449 F.2d 567 (9th Cir. 1971).

18. 531 F.2d 624 (D.C. Cir. 1976). 
to oversales by contracting for additional carrier space. Moreover, by the time the CAB finally disapproved the amended filing, many of the passengers were already in Europe. The result was that some passengers were stranded over the Labor Day weekend and the plaintiff had to purchase space for all of them on regularly scheduled airlines as it became available, thus incurring substantial losses. As the reviewing court notes, the CAB managed at a stroke to penalize a responsible carrier operating in accord with traditional industry practice and to insure the realization of the risk to passengers that the licensing scheme was meant to avoid. ${ }^{19}$

\section{Grants and Benefits}

In many ways governmental grant and benefit activities partake of both enforcement and licensing functions and give rise, when poorly administered, to similar harms. The wrongfully rejected disability applicant may suffer pecuniary injury similar to that of the wrongfully rejected applicant for a license. Granting funds to an irresponsible medical researcher or an unsafe laboratory creates risks similar to those created by licensing an unfit flight surgeon. Because most grants contain conditions for the protection of the general public or particular third-party beneficiaries, grant administration involves the usual run of enforcement tasks and their attendant potential harms.

Perhaps the peculiar risk of harm in grant or subsidy activity lies in the potential for discriminatory awards or denials. In many so-called discretionary grant programs awards are made on a competitive basis. Moreover, grant standards are amorphous at best. Yet the ability to obtain or maintain an award may make or break a career or a firm. ${ }^{20}$ The facts in Scholder $v$. United States ${ }^{21}$ provide a rustic but poignant example. Certain Indians had repeatedly petitioned the appropriate federal officials to open irrigation laterals to their land. Finally despairing of favorable action, and unable to make a go of their farms without irrigation, the Indians sold out to a white man. Strangely, the buyer's first petition for irrigation was granted. Presumably, he flourished. In the West sovereign construction of finger laterals is often tantamount to the legendary Midas touch.

\section{Proprietary Functions}

The occasions for harmful official activity that gives rise to civil liability are perhaps most numerous when officials act in proprietary capacities. Being run

19. See id. at 627 .

20. See, e.g., Hi-Ridge Lumber Co, v. United States, 443 F.2d 452 (9th Cir, 1971) (contract for sale of timber in national forest); Scanwell Laboratories, Inc. v. Shaffer, 424 F.2d 859 (D.C. Cir. 1970) (FAA contract for instrument landing systems); Kletschka v. Driver, 411 F.2d 436 (2d Cir. 1969) (Veterans' Administration research grant).

21. 428 F.2d 1123 (9th Cir.), cert. denied, 400 U.S. 942 (1970). 
over by a postal truck looks like a common, garden-variety tort. Smoke from a government heating plant seems no less a nuisance than that emanating from the private concern next door. And when the government packs fertilizer so that it behaves like incendiary bombs, ${ }^{22}$ it seems insignificant that the officials responsible receive their paychecks from the U.S. Treasury. The analogy to private functions, privately generated harms, and private civil liability is so close that a failure to hold the government or its officials liable seems strange. Yet, as we shall see, even here immunity is not uncommon.

II

\section{The Doctrine of Official Immunity}

\section{A. A Brief History}

The notion that government officers should be shielded from liability for their misconduct is of relatively recent origin. Early opinions made no distinction between public officers and ordinary citizens in determining liability for tortious conduct. Indeed, many early decisions imposed liability for official acts that were not even tortious by private-law standards. A well-known example is the 1894 opinion in Miller $v$. Horton. ${ }^{23}$ The defendant, a state health officer, had ordered the destruction of the plaintiff's horse pursuant to a Massachusetts statute directing officers to inspect horses believed to be infected with glanders and to destroy and bury diseased animals summarily. Writing for the court, the then State Justice Holmes, in a narrow interpretation of the statutory provision, typical of nineteenth-century opinions, ruled that the plaintiff could recover damages from the officer personally if the jury found that the horse had not in fact been infected. The defendant could not escape liability by showing that his action had been reasonable and in good faith, for he had authority to destroy only diseased horses.

Nineteenth-century decisions often afforded public officers little protection against liability even for actions taken in the performance of their public responsibilities: ${ }^{24}$

In sum, the officer was held personally liable not only for his negligence and omissions and for positive torts which he was not authorized to commit, but even for acts he was authorized-in-fact to do if . . . his authority to do those acts was legally insufficient. Good faith, mistake, obedience to orders, or even the noblest intentions, were no better defenses to a personal action for damages .... . These standards of personal official liability were repeatedly reaffirmed and applied during the same decades around the turn of the century when the Supreme Court was enlarging the immunity of the state; indeed it

22. Dalehite v. United States, 346 U.S. 15 (1953).

23. 152 Mass. 540, 26 N.E. 100 (1891).

24. Engdahl, Immunity and Accountability for Positive Govermmental Wrongs, 44 U. CoLo. L. REv. 1,47 (1972). 
was only for this reason that the expanding state immunity was considered to be consistent with the tradition of effective redress for positive governmental wrongs.

The same draconian principles were not, however, applied to judges. The Supreme Court recognized the threat that would be posed to judicial performance if disappointed litigants were allowed to sue personally judges who had assertedly exceeded their jurisdiction or authority. In Bradley $v$. Fisher ${ }^{25} \mathrm{Justice}^{2}$ Field explained why judges should be accorded immunity from such suits: ${ }^{26}$

Where there is clearly no jurisdiction over the subject-matter any authority exercised is a usurped authority, and for the exercise of such authority, when the want of jurisdiction is known to the judge, no excuse is permissible. But where jurisdiction over the subject-matter is invested by law in the judge ... the manner and extent in which the jurisdiction shall be exercised are generally as much questions for his determination as any other questions involved in the case. ...

. . The allegation of malicious or corrupt motives could always be made, and if the motives could be inquired into judges would be subjected to the same vexatious litigation upon such allegations, whether the motives had or had not any real existence. ... [F]or malice or corruption in their action whilst exercising their judicial functions within the general scope of their jurisdiction, the judges of these courts can only be reached by public prosecution in the form of impeachment or in such other form as may be specially prescribed.

This reasoning extended similar immunity to officers other than judges who acted for the judicial branch or were engaged in quasi-judicial functions. Still, by the mid-twentieth-century the Supreme Court had not recognized any general immunity for administrative officers below Cabinet rank. Such immunity had, however, been strongly supported by Judge Learned Hand in Gregoire $v$. Biddle, a suit against the Attorney General and subordinate immigration officials that alleged they had "maliciously and wilfully" incarcerated the plaintiff on Ellis Island without "colorable cause."27 The court held the officials absolutely immune, saying in part: ${ }^{28}$

It does indeed go without saying that an official, who is in fact guilty of using his powers to vent his spleen upon others, or for any other personal motive not connected with the public good, should not escape liability for the injuries he may so cause; and, if it were possible in practice to confine such complaints to the guilty, it would be monstrous to deny recovery. The justification for doing so is that it is impossible to know whether the claim is well founded until the case has been tried, and that to submit all officials, the innocent as well as the guilty, to the burden of a trial and to the inevitable danger of its outcome, would dampen the ardor of all but the most resolute, or the most irresponsible, in the unflinching discharge of their duties. Again

25. 80 U.S. (13 Wall.) 335 (1871).

26. Id. at 351-54.

27. 177 F.2d 579 (2d Cir. 1949), cert. denied, 339 U.S. 949 (1950).

28. Id. at 581 . 
and again the public interest calls for action which may turn out to be founded on a mistake, in the face of which an official may later find himself hard put to it to satisfy a jury of his good faith. There must indeed be means of punishing public officers who have been truant to their duties; but that is quite another matter from exposing such as have been honestly mistaken to suit by anyone who has suffered from their errors. As is so often the case, the answer must be found in a balance between the evils inevitable in either alternative. In this instance it has been thought in the end better to leave unredressed the wrongs done by dishonest officers than to subject those who try to do their duty to the constant dread of retaliation. Judged as res nova, we should not hesitate to follow the path laid down in the books.

The decisions have, indeed, always imposed as a limitation upon the immunity that the official's act must have been within the scope of his powers; and it can be argued that official powers, since they exist only for the public good, never cover occasions where the public good is not their aim, and hence that to exercise a power dishonestly is necessarily to overstep its bounds. A moment's reflection shows, however, that that cannot be the meaning of the limitation without defeating the whole doctrine. What is meant by saying that the officer must be acting within his power cannot be more than that the occasion must be such as would have justified the act, if he had been using his power for any of the purposes on whose account it was vested in him. For the foregoing reasons it was proper to dismiss the first count.

Ten years later, in 1959, the Supreme Court vindicated Judge Hand's view and applied it in a case that involved no high-ranking officials. In a plurality opinion Justice Harlan explained: ${ }^{29}$

We do not think that the principle . . can properly be restricted to executive officers of cabinet rank, and in fact it never has been so restricted by the lower federal courts. The privilege is not a badge or emolument of exalted office, but an expression of a policy designed to aid in the effective functioning of government. The complexities and magnitude of governmental activity have become so great that there must of necessity be a delegation and redelegation of authority as to many functions, and we cannot say that these functions become less important simply because they are exercised by officers of lower rank in the executive hierarchy.

To be sure, the occasions upon which the acts of the head of an executive department will be protected by the privilege are doubtless far broader than in the case of an officer with less sweeping functions. But that is because the higher the post, the broader the range of responsibilities and duties, and the wider the scope of discretion, it entails. It is not the title of his office but the duties with which the particular of ficer sought to be made to respond in damages is entrusted-the relation of the act complained of to "matters committed by law to his control or supervision,". . . which must provide the guide in delineating the scope of the rule which clothes the official acts of the executive officer with immunity from civil defamation suits.

Because the principal opinion in Barr $v$. Matteo commanded the support of only four Justices, few would have predicted that it would remain the definitive statement on the immunity of high-ranking federal administrators. Fewer

29. Barr v. Matteo, 360 U.S. 564, 572-74 (1959). 
still would have forecast the expansive reading that the opinion has subsequently received.

Garner $v$. Rathburn ${ }^{30}$ is an example of this development. The plaintiff in that case was an Air Force enlisted man assigned to work with a crew laying asphalt at his base under the supervision of Rathburn, a civilian in the employ of the Air Force, who supervised sixty-four men in all. Garner claimed that he sustained injuries when, as a result of the defendant's negligence, a defective asphalt spreader ran over his leg. The court sustained Rathburn's claim of immunity: ${ }^{31}$

[W] believe that the defendant's duties as supervisor constantly demanded the exercise of judgment and discretion over his men and equipment. . . .

... It appears to us that his functions, in relation to an important military installation, are such that to expose him to damage suits for his acts would likely inhibit the performance of his duties to the public's detriment.

Immunity may protect not only officials who have no policymaking responsibility but also individuals who have only loose ties to the government. Becker $v$. Philco Corp. ${ }^{32}$ was an action for defamation brought against Philco by two former employees for false reports made to the government that they disregarded security controls. Philco was obligated by the terms of its contract with the government to report any actions by its employees that deviated from controls on the secrecy of government information. The logic of Barr $v$. Matteo, the court concluded, sustained Philco's claim of immunity: "[W]e think the company and its trusted personnel were imbued with the official's character, and partake of his immunity to liability, whenever and wherever he would enjoy the absolute privilege." 33

Courts occasionally demonstrate unusual fervor in their concern to protect government officials from harassing litigation. In Bailey $v$. Van Buskirk, ${ }^{34}$ for example, the court ruled that two Army surgeons could not be sued for malpractice by an enlisted man who lost a kidney in an operation required to remove surgical sutures that had been left behind in a previous operation by the defendants: ${ }^{35}$

It is not yet within the American legal concept that one soldier may sue another for negligent acts performed in the line of duty. The idea is that an undisciplined army is a mob and he who is in it would weaken discipline if he can civilly litigate with others in the army over the performance of another man's army duty."

In each of the foregoing cases the defendant's assertedly tortious acts were committed in the course of activities either directed or clearly contemplated

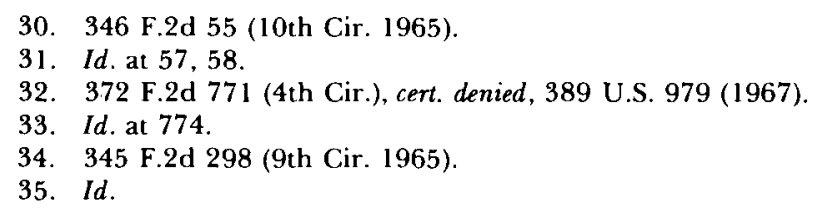


by his employer. The judicial test of entitlement to immunity is thus the propriety of the defendant's general activities rather than the nature of his particular acts. And it may fairly be said that the federal courts will afford immunity to almost any administrative officer who can show that his conduct fell generally within the scope of his assigned responsibilities. Indeed, although there are some limitations, few cases since Barr $v$. Matteo deny immunity.

\section{B. Limiting Absolute Immunity}

A notable exception to the general expansion of official immunity is Kelley v. Dunne. ${ }^{36}$ The defendant, a postal inspector, had secured entrance to the plaintiff's home for a search by knowingly misrepresenting that he was in possession of search and arrest warrants. He had also threatened force against Mrs. Kelley to gain access to part of the house. The court of appeals overturned a lower-court judgment dismissing the complaint: ${ }^{37}$

[T] he principle is established that free and untrammeled behavior of certain government representatives is so important to the public welfare that, within limits, they should not be exposed to liability for damages by charges of improper motives, or of conscious wrongdoing. The difficulty is the extent of the principle. We may note, however, certain common denominators. In the first place the conduct of the defendants in all cases, viewed without reference to the defendants' alleged motives, was within the normal scope of their agency powers. A second common denominator is that the activity of the defendant was prima facie in accordance with his duties and customary behavior. ...

Thirdly, since the doctrine of absolute immunity is based upon the relative importance of the public, as against a private, interest, application of the doctrine must vary with the relative weight of the competing interests. ...

Applying these principles to the cases at bar there would seem a substantial difference between a public information officer uttering a defamatory statement in the course of an official announcement, for example, and a postal inspector making a search without, so far as presently appears, consent or a warrant or belief that there was a warrant, and volunteering slander. The public need to protect such conduct, or conduct difficult to separate therefrom, is minimal. In the case of the head of an agency it is not only appropriate and customary to make releases, but his entire function would be basically circumscribed if danger of liability existed. The uttering of defamation by a postal inspector, on the other hand, without the assurance of a warrant, or indeed, the making of the search itself without a warrant, is, or should be, the unusual case. There would be no serious hamstringing of the activities of postal inspectors if, in the absence of a warrant, they were obligated, to some extent, to defend their actions. ...

$\cdots$

... As a public official engaged in the performance of his duty it is clear that the defendant had a conditional privilege if he did not have an absolute one. Such a privilege is a defense until "malice" is shown, the burden being on the plaintiff. ...

Lest we be misunderstood, we do not hold the officer to the same stan-

36. 344 F.2d 129 (1st Cir. 1965).

37. Id. at $132-34$. 
dard with respect to personal liability as we would the government in testing the validity of its actions. For example, a search made with a warrant supported by what is subsequently determined to be an insufficient affidavit is illegal. We would not suggest that the officer's personal liability is so easily established. [Footnote omitted.] An error in constitutional interpretation, or in concluding what are "reasonable grounds to believe" may be fatal to the government's position, but not to the officer's. Unreasonableness and recklessness are by no means equivalent.

Although courts have generally tended to accept assertions that a complained-of action was within the scope of official duties, a few courts have limited the reach of Barr $v$. Matteo by careful attention to that issue. Hughes $v$. Johnson $^{38}$ is an example. The plaintiffs, owners of a cold-storage business, sought recovery for damages resulting from the allegedly unlawful search of their business premises and seizure of game birds by federal game wardens. The court concluded that the plaintiffs had not alleged that the defendants had exceeded the then-applicable constitutional limits on warrantless inspections of business premises, and that the defendants' conduct, even if offensive and actuated by malice, was therefore not actionable. But the court went on to suggest that the plaintiffs might be able to amend their complaint to state a cause of action: ${ }^{39}$

Dismissal of the action by the district court was apparently upon the ground that even viewing this incident as an unauthorized search and seizure ... Barr v. Matteo, supra, grants immunity. With this we disagree. . . .

. . Our problem at this point does not relate to the malicious performance of official duties. The question is whether a search without warrant and unsupported by arrest, in violation of the Fourth Amendment . . . can be said to fall within the scope of the official duties of these appellees. In our view, it cannot, and accordingly immunity does not extend to such conduct.

Similarly, in Fowler v. Southern Bell Tel. E Tel. Co. ${ }^{40}$ the court of appeals reversed the dismissal of the action, which alleged tortious invasion of privacy by wiretapping, because the district court had relied on the bare assertion that the defendants had been acting within the scope of their offices: "[T]he defense of sovereign privilege imposes a drastic impingement on personal liberty, and ... should not be sustained ... in the absence of a clear and specific factual demonstration that the actions of the officers were indeed taken in pursuit of their official duties." 41

\section{Constitutional Torts and Low-Level Officials}

The immunity defense was relaxed in cases like Kelley $v$. Dunne and Hughes $v$. Johnson in the context of enforcement involving physical intrusion. These

38. 305 F.2d 67 (9th Cir. 1962).

39. Id. at 70 .

40. 343 F.2d 150 (5th Cir. 1965).

41. Id. at $154-55$. 
cases mark the convergence of two lines of development towards making this type of harm actionable. First, there is a very strong current in state common law towards according police officers only qualified immunity: an allegation of bad faith voids the immunity defense. Indeed, ordinary police officers in some jurisdictions seem to have no immunity, although the cases are difficult to parse because the cause of action asserted often requires intent bordering on willfulness. The difference between no immunity and qualified immunity is therefore often insignificant. But the police-officer cases also respond to a more general theme that the Barr opinion muffled but did not silence, that is, that low-level or "line" officers may have no immunity although their superiors are absolutely immune.

The rationale in such cases is that if the duty involves little or no discretion, the functional basis for immunity vanishes. Although seemingly sensible at first blush, the results may be peculiar. In Doe v. McMillan, ${ }^{42}$ for example, the Supreme Court suggests that the Public Printer may be liable for printing slander at the direction of a congressional committee, all of whose members are absolutely immune. Clearly the Public Printer does not exercise discretion whether to print documents at congressional direction. Do we want a liability rule that enjoins such discretion on him? To give another example, when a custodial system fails to protect mental patients, do we want to provide the hospital administrator and director of neuropsychiatry with absolute immunity while holding nursing assistants liable? ${ }^{43}$

The second line of development converging on Kelley and Hughes is the tendency of the common-law tort involved (trespass, assault, or whatever) to be conjoined with an alleged violation of a federal constitutional right. It seems likely-although the issue is as yet unresolved-that when enforcement activity violating the fourth amendment gives rise to a federal cause of action for damages, policies favoring judicial development of a damage action under the Constitution will limit the reach of the immunity doctrine. In parallel developments under title 42, section 1983, of the U.S. Code, which provides for suits against state officials for abridgement of federal constitutional rights, immunity has been qualified. In Scheuer $v$. Rhodes, for example, the court stated: ${ }^{44}$

[I]n varying scope, a qualified immunity is available to officers of the executive branch of government, the variation being dependent upon the scope of discretion and responsibilities of the office and all the circumstances as they reasonably appeared at the time of the action on which liability is sought to be based. It is the existence of reasonable grounds for the belief formed at the time and in light of all the circumstances, coupled with good-faith belief, that

42. 412 U.S. 306 (1973).

43. See, e.g., Estate of Burks v. Ross, 438 F.2d 230 (6th Cir. 1971).

44. 416 U.S. $232,247-48$ (1974). 
affords a basis for qualified immunity of executive officers for acts performed in the course of official conduct.

The next year the Court reiterated its Scheuer position in a case involving not an enforcement invasion but expulsion from public school without the constitutionally required notice and opportunity to contest. In the Court's words: ${ }^{45}$

[W]e hold that a school board member is not immune from liability for damages under $\S 1983$ if he knew or reasonably should have known that the action he took within his sphere of official responsibility would violate the constitutional rights of the student affected, or if he took the action with the malicious intention to cause a deprivation of constitutional rights or other injury to the student. . . . A compensatory award will be appropriate only if the school board member has acted with such an impermissible motivation or with such disregard of the student's clearly established constitutional rights that his action cannot reasonably be characterized as being in good faith.

Similar limitations on the immunity of federal officials may well be expected, therefore, when a constitutional tort is involved.

\section{Immunity and Negligence}

The distinction that seems to have emerged between absolute immunity for common-law torts and qualified immunity for constitutional torts obviously puts pressure on the characterization of the harm. The flexible contours of the due process clause might accommodate actions for civil-rights deprivations as varied as the failure to provide appropriate mental-health care and the erroneous publication of a person's name on a list of active shoplifters. The Court, however, is alive to the prospect of these legal sleights of hand and has begun to block the due-process avenue of redress. ${ }^{46}$ One would suspect, therefore, that the ultimate rationalization for allowing liability in such cases will come not through constitutionalizing all official injuries but through erosion of the absolute immunity doctrine.

However, even if a movement is afoot toward qualified immunity (for all but judicial and quasi-judicial officers), ${ }^{47}$ that development has little importance for negligence actions. The standard enunciated by the Court in both of the converging lines we have examined is a standard of bad faith. And while negligence, particularly gross negligence verging on recklessness, may be evidence of bad faith, it is hardly the same thing.

The present situation, then, is this: Although government officials cause harm in the execution of many different types of functions, only in enforcement activity or constitutional errors does there seem to be any limitation on

45. Wood v. Strickland, 420 U.S. 308, 322 (1975).

46. See Paul v. Davis, 424 U.S. 693 (1976).

47. See Imbler v. Pachtman, 424 U.S. 409 (1976). 
absolute official immunity; and in both areas a showing of bad faith is necessary to void the immunity defense. The one exception to this requirement is the tort of the low-level official engaged in nondiscretionary functions. But because of the perverse incentives that such liability might create for disobeying higher-level policy judgments, extension of the term "nondiscretionary" will probably be limited to essentially proprietary tasks. And here official liability is probably unimportant, because the Federal Tort Claims Act permits a suit against the government, ${ }^{48}$ which plaintiffs would almost universally prefer. In short, the entire range of official regulatory and subsidy activities is free from the potential disciplinary effect of civil suits for damages based on negligence.

\section{III}

\section{Negligence, Property Rights, and Alternative Controls}

The simple economic justification for damage remedies is that they impose the cost of harmful conduct on parties who might have avoided it, thus providing appropriate incentives for the exercise of care. The legal system thus, in general, denies private persons the right to be careless. Public officials are an exception. Because they cannot be made to bear the costs of their negligence, they can be viewed as having a special form of property: the right to be careless. This seems a strange right to confer on any group; doubly strange for a group that exerts its personal power through the coercive instruments of the state.

But an official's right to negligent conduct is limited. The exercise of that right may affect the value of his other property interests, which include a considerable bundle of rights that generally attend official position. Perhaps the clearest are the official's contract rights as a public servant: his title, pay, benefits, tenure, and prospects for advancement within or outside government. The official might also be considered to have property in the form of his authority, that is, in his ability to use state power to pursue ends which, while not exclusively his own, are usually not inconsistent with his. And given greater or lesser discretion within the boundaries of his instructions, the official may have numerous opportunities to modify societal purposes by his own preferences. Officials may also find utility in the associations, opportunities for learning, and general social milieu that are established by their position and functions.

It seems clear that negligent conduct may adversely affect all of these property interests. Negligent officials can be fined or demoted, their prospects dimmed by poor efficiency reports, their opportunity to wield power circumscribed by continuous supervision or legal limitation. And, of course, the

48. See 28 U.S.C. $\$ \S 2671-80$ (1970). 
contrary is true of the conscientious and effective public employee. The critical issue is whether these alternatives to liability provide appropriate incentives for efficient care.

The success of the existing system of rewards and sanctions requires (1) adequate incentives for bringing information about negligence (or superior performance) to the attention of an official's superiors, his prospective employers, the legislature, or the courts; and (2) conditions under which those institutions can effectively bring sanctions to bear on the official. These two conditions are obviously critical. Indeed, a discussion of the various elements of the existing controls on official conduct suggests that the weakness of those controls is perhaps the strongest argument for the use of civil damages.

\section{A. Supervisory Controls}

By virtually all accounts, the formal disciplinary apparatus of the civil service laws is little used and, where employed, tends to focus not on job performance but on that personal behavior which renders the employee unacceptable. ${ }^{49}$ Although the general standard for dismissal or suspension without pay is "such cause as will improve the efficiency of the service," 50 inefficiency is conspicuously absent from the grounds alleged in Civil Service adverse actions. $^{51}$

This is not, of course, to say that supervisors uniformly fail to punish negligent administration. Sanctions are often imposed in more subtle ways than formal adverse proceedings (e.g., reprimand, intensified supervision, reassignment). ${ }^{52}$ I know of no case in which the most extreme pecuniary sanctions available-loss of a government job or demotion-have been imposed for mere negligence.

The numerous reasons for this phenomenon can perhaps be summarized by noting simply that an official's superiors usually face significant disincentives to taking formal disciplinary action against him. The process is timeconsuming, chancy, and potentially embarrassing. Moreover, it may destroy morale and produce additional conflict with coworkers, unions, and politicians. ${ }^{53}$ A supervisor's informal alternatives-transfer, redefinition of tasks,

49. See generally R. Vaughn, The Spoiled System: A Call for Civil Service Reform (1975); Vaughn, The Personal Accountability of Public Employees, 25 Aм. U. L. Rev. 85 (1975); Merrill, Procedures for Adverse Actions Against Federal Employees, 59 VA. L. Rev. 196 (1973).

50. 5 U.S.C. $\S 7501$ (a) (1976).

51. See Merrill, supra note 49.

52. See R. Vaughn, The Spolled System, supra note 49, at 87-91.

53. Shafritz, Public Personnel Management 45-57 (1975). The Freedom of Information Act, 5 U.S.C. $\$ 552$ (1970), as amended on Nov, 21, 1974, by P.L. 93-502, 88 Stat. 1561, represents an almost singular attempt to provide some external impetus for internal sanctions by compelling Civil Service Commission proceedings whenever a reviewing court finds that a wrongful failure to disclose raises questions whether the responsible official acted arbitrarily and capriciously. 
close supervision, visible disapproval, or acquiescence in incompetence-are therefore generally preferred. Nevertheless, one should not underestimate the effects that such apparently modest sanctions can have on an official's performance. To the extent that fragile portions of the employee's bundle of rights are highly valued-as status, discretion, or harmonious associations are-modest sanctions can be quite powerful.

\section{B. Legislative and Judicial Oversight}

If the system of internal supervision can be criticized for rarely imposing any of the direct, pecuniary consequences of negligent performance on the official responsible, the system of external judicial and legislative checks is even less effective in this regard.

Legislative oversight is not continuous. It is activated by specific concerns, some programmatic, most political. Its incidence is uneven and often unpredictable. To be sure, dramatic instances of negligence on the part of administrative officials may inspire legislative interest in the workings of the bureaucracy. But even then legislative concern is not focused on particular officials, unless they are agency heads or bureau chiefs. It is instead directed at the bureaus themselves. Legislative oversight therefore reinforces supervision within the bureaucracy by providing incentives for the high-ranking official to police his shop.

Judicial review operates in a similar but more pervasive fashion. Concern is again with the bureaus-with the legality of government action. Official defendants are held accountable as representatives of the state. Official negligence in establishing the factual grounds for action or inaction will justify judicial intervention either on substantive grounds such as arbitrariness or lack of substantial evidence ${ }^{54}$ or on procedural grounds such as inadequate findings or inadequate fact-finding procedures. ${ }^{55}$ Proof of negligent conduct (indeed, often proof of a simple mistake) thus has clear legal relevance for judicial review and may actuate review for any party who can demonstrate reasonably direct injury. To this degree judicial oversight has clear advantages over legislative oversight.

But the standard judicial remedies for administrative misconduct are greatly limited because they are only preventive. The courts reverse ceaseand-desist orders, remand decisions for new hearings, or require regulatory action. They thereby circumscribe official discretion-a part of the official patrimony previously described-but the consequences of past conduct are seldom remedied. Losses remain where they lay before judicial review was begun.

54. See, e.g., National Tire Dealers \& Retreaders Ass'n, Inc. v. Brinegar, 49l F.2d 31 (D.C. Cir. 1974).

55. See, e.g., Mobil Oil Corp. v. Federal Power Comm'n, 483 F.2d 1238 (D.C. Cir. 1973). 
At the worst the result is that an official faces judicial review knowing that he may be told to stop what he or his inferiors are doing, but until ordered to cease he and his inferiors can continue to appropriate value by exercising power without the requisite care, which is costly. As a corollary, harmed parties have strong incentives to actuate judicial review only when the future conduct of an official is sufficiently important to their continuing economic or other interests to justify the expense of litigation.

\section{Procedural Constraints}

Finally, an official's power may be exercised through processes that enable affected private parties to share official discretion and to impose costs on wayward bureaucrats. Officials may be required to provide reasoned explanations, ${ }^{56}$ accept offers of data and argument, ${ }^{57}$ or submit to cross-examination, ${ }^{58}$ all in the interest of assuring careful attention to their official duties. And to the extent that these procedural requirements impose costs that devalue an official's authority and even his status, he becomes more willing to undertake informal tasks to forestall them-that is, activities that those who have the right to impose procedural costs perceive as less potentially harmful to their interests. ${ }^{59}$ Procedural protections may therefore be viewed as a prophylactic substitute for a subsequent damage action.

But there are serious limitations on the general effectiveness of such procedures in protecting against damage from official carelessness. Procedural protections are not uniform across agencies and functions, and they are not equally available to the various parties affected by official action or inaction. Moreover, formal procedures may be an inefficient substitute for civil liability. If procedural protections and liability rules cannot be adjusted at the margin because of immunity defenses, the former may lead to factfinding and deliberation expenditures that are far higher than the amount required to compensate for the negligent action they are intended to prevent.

\section{Summary of Alternative Controls}

It seems clear that a series of constraints bounds the official right to be negligent. Some, like judicial review and legislative oversight, depend heavily on the effective communication of incentives through the hierarchy. Others depend upon the relationships that officials establish with third parties through required procedures. All affect the patrimonial interests of officials in ways that are both more elusive than the direct imposition of civil liability

56. See, e.g., Wood v. Strickland, 420 U.S. 308 (1975).

57. See, e.g., Pharmaceutical Mfr's Ass'n v. Finch, 307 F. Supp. 858 (D. Del. 1970).

58. See, e.g., Wirtz v. Baldor Elec. Co., 337 F.2d 518 (D.C. Cir. 1964).

59. See, e.g., Hamilton, Procedures for the Adoption of Rules of General Applicability: The Need for Procedural Innovation in Administrative Rulemaking, 60 CAL. L. REv. 1276, 1312-13 (1972). 
for negligence and less clearly calibrated by the amount of harm caused. Existing controls are not a perfect substitute for civil-liability rules.

\section{IV}

\section{The Case Against Civil Liability}

In the absence of civil liability government officials have a bounded, uncertain, but real right to be negligent. Since no one has much to say for carelessness and since powerful arguments can be marshalled for damage actions generally, what arguments sustain the doctrine of official privilege?

\section{A. Timidity and Disproportionate Sanctions}

The major explicit reason for insulating officials from damage actions is the fear that damages will induce timidity in them. This assertion, as generally used, includes two separable assumptions. The first is that certain types of official activity would be more discouraged by the prospect of action for damages of commission than they would be encouraged by the prospect of action for damages of omission. The paradigm is officials' withholding enforcement that would serve the public interest because they fear a civil action for damages. Implicit in this argument is the notion that civil liability would have asymmetrical impacts on official functions, reenforcing an already excessive conservatism in the use of official power. But the accuracy of this proposition-which will be explored further below-has never been explicitly faced in the jurisprudence.

The second, more general argument is that civil liability would drive officials to an inappropriate level of defensive activity across the whole range of their functions. This view contemplates, for example, that an official may be likely to undertake excessive enforcement activity-in the form of additional investigation, interrogation, preliminary stop orders, or the like-in order to guard against liability for underenforcement errors. Such activity would be analogous to the defensive-medicine syndrome thought to be engendered by medical malpractice claims.

A consideration of the public official's property rights supports both assumptions. Officials obviously are limited in their ability to capture the gains from holding their caution to efficient levels. If civil liability obtained, one form of inefficient care (i.e., negligence) would entail a pecuniary sanction activated by parties who would benefit directly from its imposition. Efficient (rather than excessive) caution, however, would be rewarded only indirectly, if at all, through career advancement-marginal increases in status, pay, discretion, comfort, and the like. And since bureaucratic devices for detecting efficiency and the incentives for rewarding it seem relatively weak, it appears sensible to predict that civil liability would engender official overcautious- 
ness-characterized perhaps by the already too common bureaucratic faults of rigidity, technicality, excessive demands for information, and buck-passing. In short, the argument is that civil liability is too direct and powerful a sanction for a system of fragile or underdeveloped property rights.

Although appealing, this disproportionate-sanction argument is hardly conclusive. There is every reason to believe, for example, that in many instances the legal system imposes civil liability where property-rights regimes limit the employees' opportunities to appropriate the gains of efficient caution. The salient difference between the reward structure faced by the employee at General Motors and that faced by the official at the Department of Transportation is not their differing personal-property-rights regimes but rather the differing liability of their employers. The GM employee's risk is minimized by the obvious advantages to plaintiffs of naming his employer as a defendant, while sovereign immunity may deflect suits from the government onto government of ficials, thereby producing litigation with unlikely captions such as Bivens $v$. Six Unknown Named Agents of the Federal Bureau of Narcotics. ${ }^{6}$

The real culprit in the case of overcautiousness may indeed be sovereign, not official, immunity. But even without relaxation of the sovereign-immunity doctrine there are means of shifting the incidence of liability to the government, for example, officers' liability insurance purchased by the state. If civil liability imposed on officials were shifted in this way, the usual effects of enterprise liability might be expected: civil suits would provide both important information about where negligence occurs and incentives for internal policing that do not currently obtain. The incentives of government officials could thus be made identical to those of private-sector employees who enjoy no immunity to civil liability.

The actual effects of imposing civil liability on officials might, of course, be quite different. The government might decide that holding individual employees civilly liable is a good idea and that it would not provide insurance as a part of the employment package. Provided that a rough equilibrium exists in factor markets, this decision would reduce the effective pay rates of government officials, and a new equilibrium would have to be established. In principle there is no way to know what the new equilibrium would be, but polar possibilites can be imagined.

First, there might be no change in officials' rates of pay, perquisites, or authority. In that case there would be a general reduction in the value of government employment, and workers who now command lesser rates of pay than the current crop of government officials would gradually replace them. Alternatively, the expected value of liability (equivalent to the insurance premium that the government has decided not to pay) might be added in full to

60. 403 U.S. 388 (1971); see note 7 supra and accompanying text. 
pay scales. In that case persons more ready to accept economic risks than those currently employed by the government would find their way into public service. In both cases incentives for overcautiousness would remain. This argument against civil liability for officials is thus valid, but only if the burdens imposed were not somehow shifted onto the government.

\section{B. Harassment and Conflict of Interests}

A second and closely analogous argument against official liability is the notion, prominent in Gregoire $v$. Biddle ${ }^{61}$ that costly and time-consuming lawsuits would destroy the effectiveness of the public service. One wonders what to make of this assertion. All liability rules entail the possibility of mistaken, frivolous, even vindictive, lawsuits. Why should government officials be protected from this risk? There are, after all, constraints on harassing litigation: suing government officials is no less costly than suing private parties. And since the government usually provides funds for the officials' defense, costs of litigation provide no justification for official immunity from suit.

The puzzle may be explicable if one views the argument as merely a variant of the governmental-effectiveness argument for sovereign immunity. But such an explanation is flimsy at best. The possibilities for judicial review in nondamage modes already enable the determined plaintiff to tie up the government or its officials in litigation. And the existing legal limitations on judicial review-primarily doctrines of standing and the nonreviewability of discretionary functions-would almost certainly remain applicable (under modified terminology) in civil actions for damages.

But there may be a stronger objection here than appears from the foregoing discussion. A civil liability suit may be a special form of harassment that is more aptly characterized as the creation of disqualifying conflicts of interest. Consider, for example, the common case of a rezoning petition. If a planning commissioner has a pecuniary interest in the subject property, he is clearly disqualified from acting. And under most conflict-of-interests statutes an interest in abutting properties, in the activities of the potential lessor, or indeed any pecuniary interest that would be affected by the decision disqualifies a commissioner. The principle of such legislation ${ }^{62}$ is that policy is to be determined on the basis of public, not private, pecuniary interest.

Now consider an addition to the rezoning scenario: The petition is denied. The petitioner applies for a rehearing and concurrently files a private civil damage action for $\$ 1$ million against each planning commissioner, alleging neglect, inattention, and malice. Should the commissioners be allowed to act on the petition for rehearing? Do they not now have a private pecuniary in-

61. 177 F.2d 579 (2d Cir. 1949), cert. denied, 339 U.S. 949 (1950); see notes 27 \& 28 supra and accompanying text.

62. See, e.g., 18 U.S.C. $\S 208$ (1970). 
terest in satisfying the applicant? The contradiction between the hypothetical petitioner's suit and his new petition does not weaken the conflict; nor does the opponents' equal right to sue. Compromise decisions (or activities such as data collection, hearings, or the like) directed at satisfying the demands of potential plaintiffs are on their face not good public policy. ${ }^{63}$ Strong incentives would be present for officials both to overuse public resources (e.g., for investigation) in protecting themselves against potential private loss (e.g., for negligent inattention) and to skew their actions to favor that set of interests which presents a credible threat of suit.

To summarize, the harassment objection, viewed as analogous to a conflict-of-interests problem, both restates the timidity concern and anticipates a potential problem of skewed incentives.

\section{Skewed Incentives and Causes of Action}

There remains a final argument against official liability that may be of moment. It has apparently not been discussed elsewhere, perhaps because the immunity doctrine has prevented analysis from reaching this point. As developed here it will be known as the cause-of-action argument. While official privilege forecloses many otherwise valid claims, the complete rejection of such a defense would not necessarily expose all negligent administrators to claims for compensatory relief. Plaintiffs would, indeed should, still be required to state a cause of action having the usual elements: act, cause, damage, fault. And many official functions, when negligently performed, produce harms that seem to fit poorly within these general contours.

\section{Cause of Action in Enforcement}

There is, of course, little difficulty in finding private-law analogies for harms resulting from enforcement activities. Assault, battery, trespass, libel, all spring immediately to mind. The elements of a cause of action for failure to enforce, however, are more problematic. If the plaintiff complains of a failure to enforce, his harm results directly from the actions of third parties, not from the inaction of the enforcement official. The Supreme Court recently held, in Linda R.S. v. David D. ${ }^{64}$ that a deserted mother had no standing to sue the state prosecutor in an attempt to compel enforcement of criminal nonsupport statutes. In the Court's view, the imposition of criminal sanctions on wayward husbands, even the plaintiff's, held out no guarantee that the harm complained of-nonsupport-would be abated. There was therefore insufficient causal nexus between the prosecutor's inaction and the plaintiff's harm.

The general view of the efficacy of criminal deterrence implicit in Linda

63. See, e.g., T.J. Lowi, THE END OF LiBeralism 85-93 (1969).

64. 410 U.S. 614 (1973). 
R.S. seems peculiar, particularly in a suit for mandatory injunction that alleged complete abandonment of an enforcement function. Nevertheless, the case poses an important issue for this discussion. If abandonment of enforcement is too indirectly related to a particular harm to sustain a suit by a victim for injunctive (or even declaratory) relief, the finding that a particular amount of damage has resulted from nonenforcement would seem a fortiori foreclosed.

But enforcement is not always or even primarily through criminal process. Administrators have, inter alia, power to issue cease-and-desist orders, seek court injunctions, seize goods, and make public announcements. In many cases one or another of these enforcement devices will be both more efficacious in obtaining general compliance and more clearly related to particular harms than the imposition of criminal penalties. Where a Food and Drug Administration official, for example, has knowledge of tainted foodstuffs and fails to remove them from the market or warn the public, any resulting harm can sensibly be viewed as directly related to the official's failure to act. The issue of causation in such circumstances is still troublesome. The cause of harm lies, perhaps, somewhere between the official's failure to use criminal sanctions aggressively and a victim's reliance on a specific certification by the FDA that the foodstuffs are pure and wholesome. Nevertheless, a cause of action seems plausible, provided that the other elements of a claim can be established.

Should a plaintiff leap the causation hurdle, a claim based on nonenforcement must confront a jurisprudence that treats enforcement decisions as discretionary. Although this characterization emanates from cases that are largely unconcerned with damage actions, it also influences decisions under the Federal Tort Claims Act. ${ }^{65}$ To label a function "discretionary" is tantamount to a declaration that it carries no legal duty to enforce. Under this view neither negligent nor willful nonenforcement would be actionable.

The contemporary law is not so unsympathetic to actions for nonenforcement, however, as the general principle of prosecutorial discretion would indicate. Where violations are well known, are of constitutional significance (e.g., civil rights violations), and especially where the enforcer has virtually abandoned attempts to obtain compliance, plaintiffs have successfully invoked judicial review in an injunctive mode. ${ }^{66}$ Moreover, when a statute seems to preclude the exercise of discretion about the institution of enforcement proceedings after a preliminary finding of probable cause, courts may compel action of some sort. ${ }^{67}$ These are, however, a narrow band of cases whose

65. See, e.g., Smith v. United States, 375 F.2d 243 (5th Cir. 1967).

66. See, e.g., Adams v. Richardson, 356 F. Supp. 92 (D.D.C. 1973), aff'd in part, 480 F.2d 1159

(D.C. Cir. 1973).

67. In some cases the official action required is merely a statement of reasons for a failure to 
principled expansion is limited.

The problem, then, considered as yet solely in reference to enforcement, is to fit enforcement activities into customary modes of thinking about civil liability without skewing incentives toward underenforcement. For if the enforcer acts mistakenly, the harm and its connection to his activity are likely to be clear. His only shield will be privilege-or its equivalent formulated in terms of a lax or nonexistent standard of care. Should the enforcer fail to act, however, he will usually be insulated from liability by traditional notions of both causation and legal duty.

\section{Cause of Action in Other Functions}

The problem in licensing or certification functions is somewhat more complex. Whether the danger lies in over- or under-regulation depends upon the type of licensing function. Let us take three licensing or certification functions of the Food and Drug Administration as illustrations. First, the FDA must inspect and approve the cleanliness and quality controls of plants in which drugs are manufactured. ${ }^{68}$ Second, it must certify prior to marketing that any new drug is safe and effective for its intended uses. ${ }^{69}$ Third, the FDA approves antibiotics, vaccines, insulin products, and color additives by lots. ${ }^{70}$ What are the chances that either a negligent approval or a negligent disapproval would result in civil liability for the official responsible for carrying out these functions?

First, consider plant inspections. Given negligent failure to inspect or negligence in inspection, would the ultimate consumer of a contaminated or poor-quality drug have a cause of action against the negligent official for a resulting harm? One would think not. Proof that a biyearly inspection would have protected the plaintiff seems difficult at best. Here, as in the case of

act. See, e.g., Dunlop v. Bachowski, 421 U.S. 560 (1975), where the Court specifically refused to address the question "whether the district court is empowered to order the Secretary to bring a civil suit" (id. at 575). In other cases government officials who have delayed a decision whether to take enforcement action have been required to decide. See, e.g., Environmental Defense Fund, Inc. v. Hardin, 428 F. 2d 1093 (D.C. Cir. 1970) ("the Secretary should either decide . . . or explain the reasons for deferring the decision still further" id. at 1100); American Public Health Ass'n v. Veneman, 349 F. Supp. 1311 (D.D.C. 1972) (court requires a deadline to be set for FDA evaluation of efficacy of all drugs; also requires FDA to release all completed efficacy reports). Finally, government officials have been compelled to initiate administrative review procedures. See, e.g., Environmental Defense Fund, Inc. v. Ruckelshaus, 439 F.2d 548 (D.C. Cir. 1971). In this case the Secretary of Agriculture was compelled to post notices triggering administrative review of the registration of DDT. The plaintiff had also called for the suspension of that registration while review was underway. In response to this second complaint the court merely compelled the Secretary to state his reasons for failing to suspend the registration.

68. 21 U.S.C. $\$ 360($ h) $(1970)$.

69. 21 U.S.C. $\$ 355(\mathrm{a})$, (d).

70. That is, the FDA tests the quality and virulence of the specific substance (or a sample thereof) that is to be marketed and ingested. 21 U.S.C. $\$ 357$ (antibiotics); 21 C.F.R. $\$ 273$ (1973) (vaccines); 21 U.S.C. $\$ 356$ (1970) (insulin products); 21 U.S.C. $\$ 376$ (color additives). 
nonenforcement of criminal penalties, proximate cause is a serious if not insurmountable problem for the injured consumer. The problem might be compared to that raised by per se negligence cases in which the defendant has failed to obtain a requisite license or approval. Almost uniformly courts hold that proof of negligent primary conduct is necessary to a successful cause of action; the absence of a license is not the proximate cause of an injury. ${ }^{71}$

On the other hand, should it be determined that an inspector negligently withheld approval of a manufacturer's operations, causing a suspension of production and an attendant loss of profits, proof of the elements of a cause of action seems more straightforward. In factory inspections, as in the context of enforcement, to which they are closely allied in function, the incentives that civil liability would place on the licensor are largely in the direction of granting official approval.

The same effects do not necessarily attend attempts to attach civil liability to the other two types of FDA licensing. One would think that a manufacturer would find it extremely difficult to prove the amount of damage resulting from negligent disapproval of a new drug, for example. Potential profits are likely to be classified as speculative, and research and development costs, though ascertainable, would be lost anyway in the absence of profitability. When an FDA official negligently fails to certify a batch of vaccine or food coloring, one would imagine that the harmful publicity attending a civil suit would usually exceed the modest value of a damage recovery, from which the probability of failure must be discounted and litigation costs subtracted.

Yet negligent batch-certification, and to a lesser degree negligent approval of drugs, are failings for which the harmed consumer is most likely to maintain a successful cause of action. The statutory scheme is designed to protect the consumer, and the FDA's duty to protect is universal: it covers all new drugs and all batches. In batch certification particularly, the FDA and its employees have undertaken to perform an essential part of production, and the failure to use due care has quite predictable consequences. What little law there is on the civil liability of private testing laboratories for negligent certification of products suggests that a cause of action will be analogous to either misrepresentation or failure to warn. Indeed, one plaintiff has managed to circumvent the usual exceptions to the Federal Tort Claims Act to obtain a judgment against, not the responsible officials, but the United States for $\$ 2$ million in damages resulting from the negligent release of a batch of Sabin III polio vaccine. ${ }^{72}$

In short, the more closely the licensing function involves officials in approving the specific conduct that causes harm, the more likely it appears that

71. See, e.g., Brown v. Shyne, 242 N.Y. 176, 151 N.E. 197 (1926).

72. Griffin v. United States, 500 F.2d 1059 (3d Cir. 1974). 
the official can be held civilly responsible for negligent approvals, though his exposure is limited for negligent disapprovals. And although this skew in incentives may seem appropriate as a choice between manufacturers' profits and consumers' health, we should pause to remember the enormous but almost certainly nonactionable losses that may be imposed on potential consumers by a disapproval that keeps a needed drug off the market.

Finally, as we come to think about highly discretionary activities like grants or subsidies-or even benefits and entitlements-the pervasive asymmetry of civil liability is more apparent. Only rejected applicants or their third-party beneficiaries will be able to make a plausible case of injury from negligent or malicious disapproval of an application. Approvals will go unchecked by civilliability rules, unless the conditions on a grant operate as a license that protects certain third parties. ${ }^{73}$

\section{$\mathrm{V}$}

\section{Some Directions for Further Inquiry}

While the foregoing discussion hardly provides the basis for a prescriptive conclusion, it does suggest some lines of inquiry that might clarify any proposal for reordering the civil-liability rules applicable to government officials. These suggestions for further exploration relate to three previously identified areas of concern: (1) the superior efficiency of civil liability over other monitoring devices; (2) the need to balance the positive and negative aspects of officials' job-related patrimony; and (3) the need to select an appropriate defendant.

\section{A. An "Information" Approach to Relative Efficiency}

The major strength of civil liability is its ability to generate and effectively communicate information about the external costs of negligent official activity. If, as seems likely, certain types of official functions are less susceptible than others of being controlled or monitored through the traditional modes of judicial review, legislative oversight, and procedural safeguards, these functions would be particularly strong candidates for the introduction of civil liability. Although it is certainly not clear at this point which functions these are, perhaps they could be defined in part as those official activities that are relatively decentralized (e.g., police activity), that are outside the areas of major policy concern for an agency or its habitual clientele (e.g., routine housekeeping activities), or that involve general skills and procedures rather than a bureau's expertise (e.g., truck driving versus vaccine testing) - in short, situations in which agency collection and use of information about employee negligence is costly or undervalued. If this definition or something akin to it

73. See, e.g., King v. Smith, 392 U.S. 309 (1968). 
proves accurate, then the current judicial movement to relax official immunity is operating in precisely those areas where reform is most needed.

\section{B. Trusteeship Liability: A Sanction Proportionate to Patrimony}

Although public officials have few opportunities to appropriate the value generated by efficient caution, they do reap the benefits of public employment. Hence it might be feasible to devise legislation for a remedy that involved, not compensation for injury resulting from negligent conduct, but forfeiture of a portion of an official's salary upon proof of his inattention or negligence in his official duties. ${ }^{74}$ The action could be made available to any person adversely affected by official negligence, and the forfeiture paid to the successful plaintiff. Such an action would combine a proportionate sanction with some incentive for injured private parties to police official negligence. ${ }^{75}$ Because the action would be for mismanagement or breach of trust through negligence (or willful inattention), and the remedy limited to a forfeiture of a portion of salary, there would be no need to demonstrate all the elements of a common-law tort action. In principle the remedy would be available where either action or inaction constituted a breach of the general duty to exercise official power prudently.

\section{Bureaus and Bureaucrats and Appropriate Defendants}

While this discussion has concentrated on the liability of officials and has sometimes alluded to the liability of the government, there is a possible middle level of responsibility: the bureaus. Some work has been done on the incentives of high level officials that suggests a strong positive relationship between policy or management choices and their effects on a bureau's budget. ${ }^{76}$ It seems clear that bureaus may have different incentives for policing negligent conduct within this one dimension. ${ }^{77}$ Negligent grant approvals in an open-ended formula-grant program would obviously increase the budget. However, inattention to violations of a regulatory statute would lead a bureau to understate enforcement problems and resource needs. A much more detailed study of bureau incentives as they would affect bureau responsibility for negligence is needed, therefore, before one can predict where such responsibility might lead.

74. For a somewhat similar proposal see R. VAughn, The SPoiled System, supra note 49, at $157-163$.

75. The idea here is to combine enforcement of the official's duty of care by victims of his negligence with a modification of official property rights, while limiting incentives for overenforcement by the private parties empowered to bring suit. See generally Becker \& Stigler, Law Enforcement, Malfeasance and Compensation of Enforcers, 3 J. Legal. STUd. 1 (1974). But see Landes \& Posner, The Private Enforcement of Law, 4 J. Legal Stud. 1 (1975).

76. W. Niskanen, Bureaucracy and Representative Government (1971).

77. See generally S. Ackerman, The Economics of Corruption (forthcoming). 